\title{
Spectrum of hemoglobinopathies in a tertiary care centre
}

\author{
Nisha Sharma ${ }^{1}$, Anil Dev Pant ${ }^{1}$, Usha Manandhar ${ }^{1}$ \\ ${ }^{I}$ Department of Pathology, Institute of Medicine, Tribhuvan University Teaching Hospital, Maharajgunj, Kathmandu, Nepal.
}

\section{Keywords:}

$\mathrm{HbD} / \mathrm{HbE}$

hemoglobinopathies;

Hemoglobin

electrophoresis;

Hemoglobinopathies;

Sickle cell disorders;

Thalassemia;

\begin{abstract}
Background: Thalassemia and other structural hemoglobinopathies are the most common single gene disorders throughout the world with the highest frequency in the tropics, subtropics, Mediterranean basin and Southeast Asia. This study aims to provide a better assessment on the spectrum of hemoglobinopathies in our context.
\end{abstract}

Materials and Methods: This descriptive study was done at our tertiary care center, from November 2014 to October 2015. Hematological indices were derived from coulter counter, haemoglobin electrophoresis was carried out by cellulose acetate medium at alkaline PH. Sickling test, $\mathrm{Hb} \mathrm{H}$ inclusions demonstration and $\mathrm{Hb} \mathrm{F}$ estimation were performed. Parental screening was done wherever feasible.

Results: Out of 350 cases referred from various out-patient departments of TUTH and different peripheral hospitals for suspected hemoglobinopathies, 97 cases $(27.71 \%)$ had hemoglobinopathies. The most predominant hemoglobinopathy was thalassemia $(57.73 \%)$ followed by sickle cell disorders $(28.87 \%)$ and $\mathrm{Hb} \mathrm{D} / \mathrm{Hb} \mathrm{E}$ hemoglobinopathies (13.40\%). Most disorders were observed in the age group 21-30 years with many of the cases seen clustered in the families and a slight male preponderance. Terai region (71.13\%) had a very high number. A significant high frequency of thalassemia (33.93\%) and sickle cell disorders $(75 \%)$ were seen in Tharu community.

Conclusion: Hemoglobinopathies were seen widespread in Nepal. An extensive screening of the population is important to assess the prevalence of hemoglobinopathies, which will help in identification of carriers and take adequate therapeutic and preventive measures.

\section{Correspondence:}

Dr. Nisha Sharma, $M D$

Lecturer, Department of Pathology,

Tribhuvan University Teaching Hospital, Kathmandu, Nepal.

ORCID ID: 0000-0001-8672-0137

Email: drnishasharma@iom.edu.np

Reveived : January $23^{\text {rd }} 2020$; Accepted : Feburary $16^{\text {th }} 2020$

Citation: Sharma N, Pant AD, Manandhar U. Spectrum of hemoglobinopathies in a tertiary care centre. JPN 2020;10: :1645-9 DOI: 10.3126/jpn.v10i1.27369

Copyright: This is an open-access article distributed under the terms of the Creative Commons Attribution 4.0 International License, which permits unrestricted use, distribution, and reproduction in any medium, provided the original author and source are credited.

\section{INTRODUCTION}

Hemoglobinopathies are characterized by the presence of structurally defective haemoglobin $(\mathrm{Hb})$ due to abnormalities in the formation of globin moiety of the molecule. ${ }^{1}$ Hemoglobinopathies fall into two main groups: thalassemia syndromes and structural hemoglobin variants (abnormal hemoglobin). ${ }^{2}$

$\alpha$-thalassemia and $\beta$-thalassemia are characterized by absent or decreased production of $\alpha$ - and $\beta$-globin subunits respectively. Sickle cell disease is caused by a point mutation in the sixth position of $\beta$-globin.3Hemoglobin 
Table 1: Sex distribution of patients

\begin{tabular}{lcccc}
\hline Sex & Thalassemia n(\%) & $\begin{array}{c}\text { Sickle Cell Discorders n } \\
(\mathbf{\%})\end{array}$ & $\begin{array}{c}\text { Others } \\
\mathbf{n}(\mathbf{\%})\end{array}$ & $\begin{array}{c}\text { Total } \\
\mathbf{n}(\mathbf{\%})\end{array}$ \\
\hline Male & $34(60.70)$ & $16(57.10)$ & $7(53.80)$ & $57(58.76)$ \\
Female & $22(39.30)$ & $12(42.90)$ & $6(46.20)$ & $40(41.24)$ \\
Total & $\mathbf{5 6 ( 1 0 0 )}$ & $\mathbf{2 8 ( 1 0 0 )}$ & $\mathbf{1 3 ( 1 0 0 )}$ & $\mathbf{9 7}(\mathbf{1 0 0})$
\end{tabular}

$\mathrm{D}(\mathrm{Hb} \mathrm{D})$ disease is derived from a point mutation in the $\beta$-globin gene with the substitution of glutamine for glutamic acid at $121^{\text {st }}$ position. ${ }^{4}$ Hemoglobin E ( $\mathrm{Hb} \mathrm{E}$ ) is produced due to the substitution of lysine for glutamic acid at $26^{\text {th }}$ position. ${ }^{5}$ This study was designed to provide a better assessment on the spectrum of hemoglobinopathies in Nepal. The frequencies of various hemoglobinopathies, age and sex distribution, geographical distribution, ethnic communities commonly affected were analysed and compared between different disorders.

\section{MATERIALS AND METHODS}

This descriptive study is a hospital based cross-sectional study carried out in the Department of Pathology, TUTH. The study duration was of one year (November 1, 2014 to October 31, 2015). Ethical approval was obtained from Institutional Review Board of the institute and consent was taken while filling the proforma. 350 patients were initially registered for the work up of hemoglobinopathies. Out of 350 cases, 97 were diagnosed to have hemoglobinopathies. The study included 97 samples for further analysis. Patients with inconclusive/normal $\mathrm{Hb}$ electrophoresis results, the repetition of the same case, those who received blood transfusion three months back were excluded from the study. EDTA anti-coagulated blood was used. Hematological indices were derived from Sysmex 500i 5-part coulter counter. Morphological alterations in red cells were studied. Hemoglobin electrophoresis was carried out by cellulose acetate medium at alkaline $\mathrm{PH}$. Other tests as sickling test using sodium metabisulfite, $\mathrm{HbH}$ inclusions (Golf balls) demonstration using brilliant cresyl blue stain, and $\mathrm{Hb} \mathrm{F}$ estimation by Singer's method were performed. Detailed history (like age, sex, caste, ethnicity, and place of origin) was recorded. Parental screening was done to confirm the diagnosis wherever feasible. The data collection was done in pre-designed proforma and data entry was done in SPSS and results were computed using Statistical Package for the Social Sciences (SPSS) version 20.

\section{RESULTS}

A total number of 350 blood samples were received in the Department of Pathology for hemoglobin electrophoresis during the study period of one year, out of which 97 cases (27.71\%) had hemoglobinopathies.

There were 56 cases $(57.73 \%)$ of thalassemia constituting the most predominant one, followed by 28 cases $(28.87 \%)$ of sickle cell disorders. Remaining 13 cases (13.40\%) were comprised by $\mathrm{Hb} \mathrm{D}$ and $\mathrm{Hb} \mathrm{E}$ hemoglobinopathies with 3 cases $(3.09 \%)$ of $\mathrm{HbD}$ hemoglobinopathies and 10 cases (10.31\%) of $\mathrm{HbE}$ hemoglobinopathies. Out of 97 cases of hemoglobinopathies, $57(58.76 \%)$ were males and 40 $(41.25 \%)$ were females in the ratio of $1.4: 1$, thus showing a preponderance of males over females (Table 1).

Thalassemia, sickle cell disorders, $\mathrm{Hb} \mathrm{D} / \mathrm{Hb} \quad \mathrm{E}$ hemoglobinopathies were more common in Terai region, the malaria endemic zone $(71.13 \%)$, followed by Kathmandu $(15.46 \%)$ and Hills (13.40\%). Maximum cases of hemoglobinopathies were between 21-30 years of age group followed by patients under 10 years of age. Likewise, Terai Janajati had the highest frequency of hemoglobinopathies $42(43.30 \%)$ followed by Hill Janajati 24 (24.74\%) (Table 2).

Electrophoresis findings of 97 cases were noted based on the bands seen on Hemoglobin electrophoresis at alkaline $\mathrm{pH}$. $\beta$-Thalassemia trait was the most common hemoglobinopathy $(36,37.11 \%)$, followed by sickle cell trait $(16,16.49 \%), \beta$-Thalassemia Major $(9,9.28 \%)$ and Sickle $\beta$-Thalassemia $(7,7.22 \%$ ) (Table 3).

Among the districts, Dang accounted for the majoritywith 26 cases (Fig. 1). Few hemoglobinopathies with their bands are depicted (Fig. 2).

\section{DISCUSSION}

Hemoglobinopathies affect people worldwide including Nepal. However, there is a limitation of scientific study which demonstrates the actual burden of the same. This study made evident that hemoglobinopathies were seen widespread in Nepal. Thalassemia were the most common constituting $57.73 \%$ of the total cases, the findings being broadly consistent with the studies done by Mondal et al in India and Waheed et al in Pakistan. 7 Modell et al reported that sickle cell disorders are the most common hemoglobinopathies. ${ }^{8}$ This means different hemoglobinopathies have diverse frequencies across the world. The present study that embodied 97 patients consisted of $57(58.76 \%)$ males and $41(41.20 \%)$ females in the ratio of 1.4:1 thus giving a preponderance of males over females. The findings were comparable to the study done in Orissa, India by Balgir et al. ${ }^{9}$ Similarly, Hussain et al came up with correspondent findings in a study done in Pakistan where $35(56.50 \%)$ males and $27(43.50 \%)$ females 
Table 2: Caste/Ethnicity distribution of patients (categorisation as per 2001 census)

\begin{tabular}{|c|c|c|c|}
\hline Ethnic Group & $\begin{array}{c}\text { No of } \\
\text { Patients } \\
\text { (Caste) }\end{array}$ & $\begin{array}{l}\text { No of Patients } \\
\text { Percentage } \\
\text { (Ethnicity) }\end{array}$ & $\begin{array}{c}\text { Male/ } \\
\text { Female }\end{array}$ \\
\hline HILL BRAHMIN & & 10 & 10.31 \\
\hline Adhikari & 3 & & \\
\hline Dhital & 1 & & \\
\hline Gautam & 3 & & \\
\hline Regmi & 3 & & \\
\hline HILL CHHETRI & & 10 & 10.31 \\
\hline Kunwar & 1 & & \\
\hline Thapa & 3 & & \\
\hline Achhami & 3 & & \\
\hline Rokka & 3 & & \\
\hline HILL JANAJATI & & 24 & 24.74 \\
\hline Kumal & 3 & & \\
\hline Lama & 3 & & \\
\hline Magar & 3 & & \\
\hline Majhi & 6 & & \\
\hline Rai & 6 & & \\
\hline Tamang & 3 & & \\
\hline TERAI JANAJATI & & 42 & 43.30 \\
\hline Chaudhary & 41 & & \\
\hline Dhimal & 1 & & \\
\hline $\begin{array}{l}\text { TERAI/MADHESI } \\
\text { BRAHMIN/ } \\
\text { CHHETRI }\end{array}$ & & 11 & 11.34 \\
\hline
\end{tabular}

Table 3: Final Diagnosis of the patients with various bands

\begin{tabular}{|c|c|c|c|}
\hline Disease & Types of bands & $\begin{array}{l}\text { Frequency } \\
\quad(\mathbf{n}=97)\end{array}$ & Percent \\
\hline Hb H Disease & Fast Moving Band & 5 & 5.15 \\
\hline$\alpha$-Thalassemia Trait & Normal band & 6 & 6.19 \\
\hline$\beta$-Thalassemia Major & $\mathrm{HbF}$ & 9 & 9.28 \\
\hline$\beta$-Thalassemia Trait & $\mathrm{HbA}+\mathrm{HbF}+\mathrm{HbA} 2$ & 36 & 37.11 \\
\hline Sickle Cell Disease & $\mathrm{HbS}$ & 5 & 5.15 \\
\hline Sickle Cell Trait & $\mathrm{HbS}$ & 16 & 16.49 \\
\hline Sickle $\beta$-Thalassemia & $\mathrm{HbS}$ & 7 & 7.22 \\
\hline Hb E Disease & $\begin{array}{l}\mathrm{Hb} \mathrm{A} 2, \mathrm{C}, \mathrm{E}, \\
\text { OArab region }\end{array}$ & 1 & 1.03 \\
\hline E $\beta$-Thalassemia & $\begin{array}{l}\mathrm{Hb} A 2, \mathrm{C}, \mathrm{E}, \\
\text { OArab region }\end{array}$ & 3 & 3.09 \\
\hline E Thalassemia Trait & $\begin{array}{c}\mathrm{Hb} \mathrm{A} 2, \mathrm{C}, \mathrm{E}, \\
\text { OArab region }+\mathrm{Hb} \\
\text { A }\end{array}$ & 6 & 6.19 \\
\hline Hb D Disease & $\mathrm{HbS}$ & 1 & 1.03 \\
\hline Hb D Trait & $\mathrm{HbS}$ & 2 & 2.06 \\
\hline Total & & 97 & 100 \\
\hline
\end{tabular}

had hemoglobinopathies out of 62 patients revealed higher frequencies of hemoglobinopathies in males. ${ }^{10}$

In our context, $49.48 \%$ of the hemoglobinopathies were seen in the age group 21-30 years, followed by $23.71 \%$ under 10 years of age. Whereas, Tiwari in her study in Nepal had drawn the conclusion of maximum cases in under-10 age group. ${ }^{11}$ This could be because in our context parental screening was done for almost all cases of homozygous hemoglobinopathies, and majority of the parents fell into that age range.

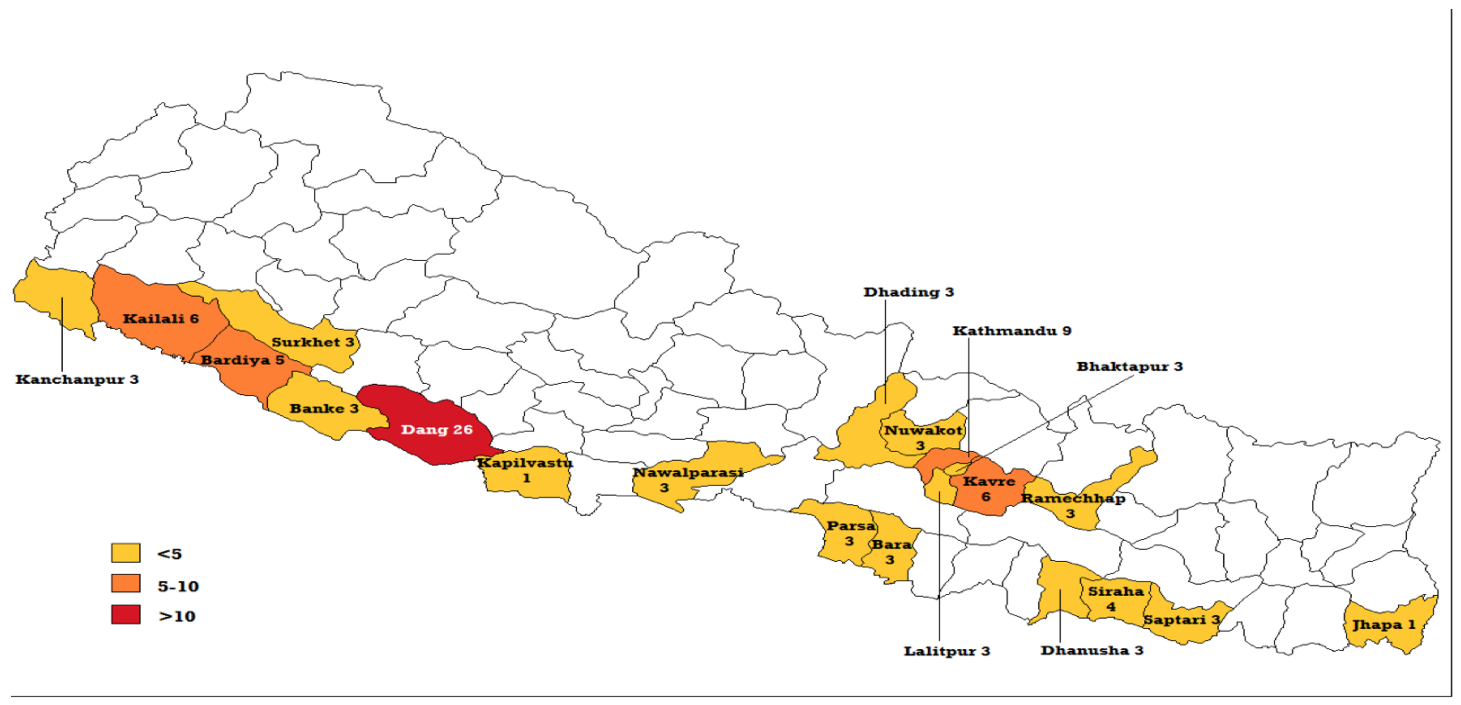

Figure 1: Map of Nepal showing various districts affected by hemoglobinopathies. Dang district, in Terai terrain accounted for the majority (26 cases) 

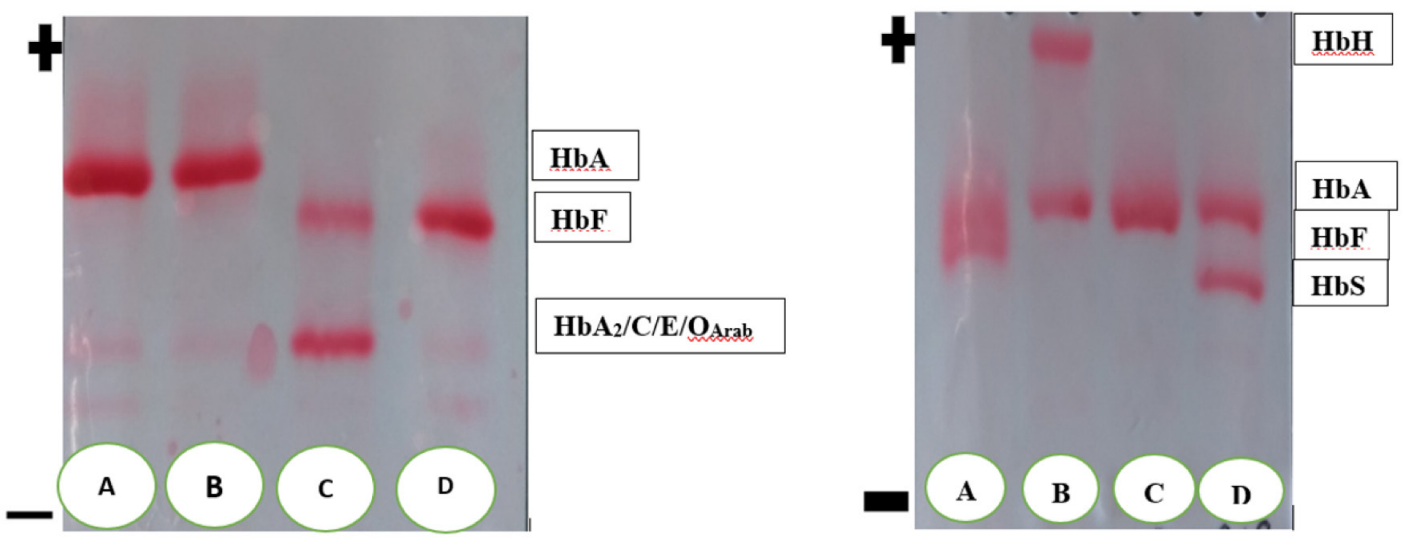

Figure 2: Bands of different hemoglobinopathies

Left: A, B: Band in Hb A region (Normal control); C: Faint band at HbF region and strong band in the region of $\mathrm{Hb} A 2, C$, E, OArab (E $\beta$-thalassemia); D: Strong Hb F band ( $\beta$-Thalassemia major patient)

Right: B: Fast moving Hb H band along with Hb A band (Hemoglobin H Disease); C: Control; D: Bands in the region of hemoglobin A

Terai janajati (Tharu/Chaudhary and Dhimal communities) had the highest and a substantial risk of hemoglobinopathies with high prevalence of both thalassemia and sickle cell disorders comprising 42 cases $(43.30 \%)$ similar to the conclusions drawn by Tiwari and Shrestha et al in their studies conducted in Nepal. ${ }^{11,12}$ Terai region is an endemic zone for malaria. The increased percentage of thalassemia and sickle cell disorders in Terai region in our research also supports several studies as Enevold et al in Tanzania population and Kuesap et al in Thailand. ${ }^{13,14}$ In addition, the practice of consanguineous marriages also contributes to higher rate of hemoglobinopathies in the Terai region.

The most predominant hemoglobinopathy was $\beta$-thalassemia trait (36 cases, $37.11 \%$ ), the observations being congruent with the studies in Eastern India and in Pakistan. ${ }^{6,10}$ Maximum cases were the parents of children with homozygous diseases such as $\beta$-thalassemia major, Sickle $\beta$-thalassemia and E $\beta$-thalassemia. The $\mathrm{HbS}$ $\beta$-thalassemia patients had a more severe disease with lower $\mathrm{Hb}$ level, MCV (8.57 g/dl, 64.17fl) as compared to HbSS $(8.86 \mathrm{~g} / \mathrm{dl}, 67.08 \mathrm{fl})$ which was comparable to the study done in Central India. ${ }^{15}$ Our research also touched on a few rarer hemoglobinopathies as hemoglobin D hemoglobinopathies which are seen sporadically in Blacks and Europeans. Fast moving $\mathrm{Hb} \mathrm{H}$ bands were seen in 5 cases $(5.15 \%)$ of all the hemoglobinopathies embracing three children and two adults. Furthermore, numerous $\mathrm{HbH}$ inclusions were demonstrated with brilliant cresyl blue stain. Nadkarni et al in his paper "Molecular diversity of Hemoglobin H Disease in India" has unequivocally elucidated that $\mathrm{Hb} \mathrm{H}$ disease is the most severe form of $\alpha$-thalassemia compatible with life. ${ }^{16}$ This statement was consonant with our results as age at diagnosis varied from 11 months to 32 years. E-thalassemia trait and $\mathrm{Hb}-\mathrm{E}$ disease in our context was $6.19 \%$ and $1.03 \%$ which was almost similar to the values found in Thailand where the prevalence was $5.2 \%$ and $0.9 \%$ respectively. ${ }^{17}$ These findings are also akin to other studies that show hemoglobin E hemoglobinopathies to be common among Southeast Asians. ${ }^{18}$

Hemoglobinopathies pose considerable economic and psychosocial burden on the affected individuals, families, society and the country, at large. This study through its findings aims to come up with conclusive results that will help to induce changes and amendments in the health sector for instance, screening of the population, identification of carriers and adoption of appropriate measures for prevention of hemoglobinopathies.

\section{LIMITATION}

The study being an institutional study, samples in our research may not be representative of the whole nation. Some of the disorders may require HPLC and capillary hemoglobin electrophoresis along with DNA testing for confirmation not available in our institute.

\section{CONCLUSIONS}

This study made evident the widespread prevalence of hemoglobinopathies in Nepal. The population of Nepal, essentially those from Terai territory were seen the most significant group affected by hemoglobinopathies. Thalassemia was seen to be the most prevailing hemoglobinopathies followed by sickle cell disorders and $\mathrm{HbD} / \mathrm{HbE}$ hemoglobinopathies. Tharu/Chaudhary population was seen to be the predominant ethnic tribes affected by the same with many of the cases seen clustered in the families. Hemoglobinopathies pose considerable economic and psychosocial burden on the affected individuals, families, society and the country, at large. 
It is very important that the population be screened so that carriers could be detected and informed about the various complications and reproductive risks. In addition, preventive measures could also be adopted in the form of genetic counseling, prenatal diagnosis and termination of the affected babies.

\section{ACKNOWLEDGMENT}

Authors would like to express sincere gratitude to Mr. Arun Joshi for technical support.

\section{Conflict of interest: None}

\section{REFERENCES}

1. Kumar V, Abbas AK, Aster JC.Red Blood cell and bleeding disorders. In: Robbins and Cotran Pathologic Basis of Disease. 9th ed. Haryana (India): Reed Elsevier; 2015. p. 629-67

2. Weatherall DJ. The Thalassemias: Disorders of Globin Synthesis. In: Kaushansky K, Lichtman MA, Prchal JT, Levi MM, Press OW, Burns LJ, et al. Williams Hematology. 9th ed. New York(USA):McGraw-Hill; 2016. p. 725-58.

3. Bunn HF. Pathogenesis and treatment of sickle cell disease. $\mathrm{N}$ Engl J Med. 1997;337:762-9. Crossref

4. De Souza Torres L, Okumura JV, da Silva DGH, BoniniDomingos CR. Hemoglobin D-Punjab: origin, distribution and laboratory diagnosis. Rev Bras Hematol Hemoter. 2015;37:120-6. Crossref

5. Yedla N, Kuchay MS, Mithal A. Hemoglobin E disease and glycosylated hemoglobin. Indian J Endocrinol Metab. 2015;19:683. Crossref

6. Mondal SK, Mandal S. Prevalence of thalassemia and hemoglobinopathy in eastern India: A 10-year highperformance liquid chromatography study of 119,336 cases. Asian J Transfus Sci. 2016;10:105. Crossref

8. Waheed U, Satti H, Farooq N, Zaheer H. Frequency of haemoglobinopathies: a single-centre, cross-sectional study from Islamabad, Pakistan. East Mediterr Health J. 2012 Dec;18:1257-9. 12):1257-9. Crossref

8. Modell B, Darlison M. Global epidemiology of haemoglobin disorders and derived service indicators. Bulletin of the World Health Organization. 2008;86:480-7. Crossref

9. Balgir R. Spectrum of hemoglobinopathies in the state of Orissa, India: a ten years cohort study. JAPI. 2005;53:10216. Website
10. Hussain J, Khan H, Ali SA, Jan MA. Haemoglobinopathies in Southern Areas of Khyber Pakhtunkhwa. J Med Sci. 2015;23:73-76. Website

11. Mamata T. Study of prevalence of different types of hemoglobinopathies in microcytic hypochromic anemias and analysis of the $\mathrm{RBC}$ indices and $\mathrm{Hb}$ levels along with clinical presentation in these conditions. 2003. Forthcoming.

12. Shrestha A, Karki S. Analysis of sickle hemoglobin. J Pathol Nep. 2013;3:437-440. Crossref

13. Alifrangis M, Dalgaard MB, Lusingu JP, Vestergaard LS, Staalsoe T, Jensen AT, et al. Occurrence of the Southeast Asian/South American SVMNT haplotype of the chloroquineresistance transporter gene in Plasmodium falciparum in Tanzania. Journal of Infectious Diseases. 2006;193:1738-41. Crossref

14. Kuesap J, Chaijaroenkul W, Rungsihirunrat K, Pongjantharasatien K, Na-Bangchang K. Coexistence of Malaria and Thalassemia in Malaria Endemic Areas of Thailand. The Korean journal of parasitology. 2015;53:265. Crossref

15. Urade BP. Incidence of sickle cell anaemia and thalassaemia in central India. Open Journal of Blood Diseases. 2012;2:71. Crossref

16. Nadkarni AH, Nair SB, Italia KY, Warang P, Dalvi M, Ghosh $\mathrm{K}$, et al. Molecular diversity of hemoglobin $\mathrm{H}$ disease in India. Am J Clin Pathol. 2010;133:491-4. Crossref

17. Nuinoon M, Kruachan K, Sengking W, Horpet D, Sungyuan U. Thalassemia and Hemoglobin E in Southern Thai Blood Donors. Advances in Hematology. 2014;2014. Crossref

18. Katsanis E, Luke K-H, Hsu E, Yates J. Hemoglobin E: a common hemoglobinopathy among children of Southeast Asian origin. CMAJ: Canadian Medical Association Journal. 1987;137:39. Website 